\title{
Synthesis, Structure and Reactivity of Zwitterionic Divalent Rare-Earth Metal Silanides
}

\author{
Vidura D. Thalangamaarachchige ${ }^{\mathrm{a}}$, Daniel K. Unruh ${ }^{\mathrm{a}}$, David B. Cordes ${ }^{\mathrm{b}}$, Clemens Krempner ${ }^{\mathrm{a}}{ }^{\text {* }}$ \\ ${ }^{a}$ Department of Chemistry and Biochemistry, Texas Tech University, Box 1061, Lubbock, Texas, USA, 79409-1061 \\ ${ }^{\mathrm{b}}$ School of Chemistry, University of St Andrews, North Haugh, St Andrews, Fife, KY16 9ST, United Kingdom \\ Supporting Information Placeholder
}

\begin{abstract}
The synthesis and structures of the first zwitterionic divalent rare-earth metal silanides of the formula $\left[\mathrm{Si}\left(\mathrm{SiMe}_{2} \mathrm{OMe}\right)_{3}-\kappa^{3}\right]_{2} \mathrm{M},(\mathrm{M}-3)$, where $\mathrm{M}=\mathrm{Eu}, \mathrm{Yb}, \mathrm{Sm}$, is reported. M-3 compounds feature spirocyclic bicyclooctane structures in which the central rare-earth metal ions are being octahedrally coordinated by six methoxy groups. The reaction of $\mathrm{Yb}-3$ with $\mathrm{BPh}_{3}$ and $\mathrm{W}(\mathrm{CO})_{6}$, resp., generated the trinuclear zwitterions $\left[\mathrm{Ph}_{3} \mathrm{BSi}\left(\mathrm{SiMe}_{2} \mathrm{OMe}\right)_{3}-\kappa^{3}\right]_{2} \mathrm{Yb}, \quad(\mathrm{Yb}-4), \quad$ and $\left[(\mathrm{CO})_{5} \mathrm{WSi}\left(\mathrm{SiMe}_{2} \mathrm{OMe}\right)_{3}-\kappa^{3}\right]_{2} \mathrm{Yb},(\mathrm{Yb}-5)$, in good yield.
\end{abstract}

Zwitterionic silanides are an emerging class of donorsubstituted silyl anions ${ }^{1,2}$ that are potentially useful as ambidentate ligands to support main group and transition metals. ${ }^{3-10}$ Interest in these types of highly reactive zwitterions primarily arises from the "naked" silyl anion that is rigidly locked and insulated from the metal cation by internal donor bridges. Unlike tetracoordinate borate-based zwitterions ${ }^{11}$, zwitterionic silanides are tri-coordinated and consequently contain a stereochemically active electron pair localized at the silyl anion, which behaves as a Lewis base that can bind to electrophilic transition and main group metal centers (Scheme 1).

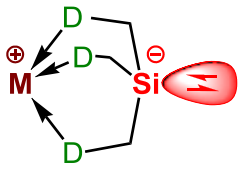

zwitterionic metal silanide

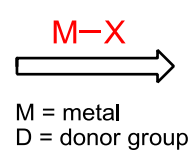

$\mathrm{D}=$ donor group

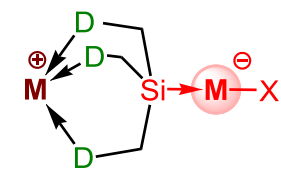

hetero-bimetallic zwitterion
Scheme 1. Design of hetero-bimetallic zwitterions.

In this regard, we recently reported the synthesis and discrete structures of zwitterionic alkali metal silanides of the formula $\left[\mathrm{Si}\left(\mathrm{SiMe}_{2} \mathrm{OCH}_{2} \mathrm{CH}_{2} \mathrm{OMe}\right)_{3}-\kappa^{6}\right] \mathrm{M}(\mathrm{M}=\mathrm{Li}, \mathrm{Na}, \mathrm{K})$ and demonstrated that the charge separated, "naked" silyl anion is available for additional metal binding, allowing for the synthesis of novel zwitterionic hetero-bimetallic silanides. ${ }^{6,8}$ In addition, we succeeded in synthesizing and structurally characterizing novel zwitterionic alkaline earth metal silanides of formula $\left[\mathrm{Si}\left(\mathrm{SiMe}_{2} \mathrm{OMe}\right)_{3}-\kappa^{3}\right]_{2} \mathrm{M}(\mathrm{M}=\mathrm{Mg}, \mathrm{Ca}, \mathrm{Sr}, \mathrm{Ba})$. These discrete homoleptic complexes represent the first examples of metalcontaining zwitterions that are composed of two "naked" silyl anions. ${ }^{7}$ On the other hand, zwitterionic silanides of the rare-earth metals regardless of their oxidation state have not been prepared so far. Herein, we report on the synthesis and structures of the first zwitterionic divalent europium, ytterbium and samarium silanides and the reaction behavior of the divalent ytterbium silanide toward $\mathrm{BPh}_{3}$ and $\mathrm{W}(\mathrm{CO})_{6}$.

The zwitterionic alkaline earth metal silanides, $\left[\mathrm{Si}\left(\mathrm{SiMe}_{2} \mathrm{OMe}\right)_{3}-\kappa^{3}\right]_{2} \mathrm{M},(\mathrm{M}-3),(\mathrm{M}=\mathrm{Mg}, \mathrm{Ca}, \mathrm{Sr}, \mathrm{Ba})$ can conveniently be synthesized via selective $\mathrm{Si}-\mathrm{Si}$ bond cleavage of $\mathrm{Si}\left(\mathrm{SiMe}_{2} \mathrm{OMe}\right)_{4},(\mathbf{1})$, with commercially or synthetically readily available metal alkoxides, $\mathrm{M}(\mathrm{OR})_{2}(\mathrm{M}=\mathrm{Ca}, \mathrm{Sr}, \mathrm{Ba})$ in tetrahydrofuran (THF) as the solvent (Scheme 2). ${ }^{7}$ Owing to their zwitterionic nature, M-3 compounds proved to be poorly soluble, even in THF, and precipitated from the reaction mixture as crystalline materials, which greatly facilitated their isolation and purification. For the synthesis of the zwitterionic divalent rare earth silanides M-3 (M = Eu, Yb, Sm), assumed to be of low solubility similar to that of their alkaline earth counterparts, salt metathesis as an alternative route was envisioned because of the lack of commercially available divalent rare-earth alkoxides.

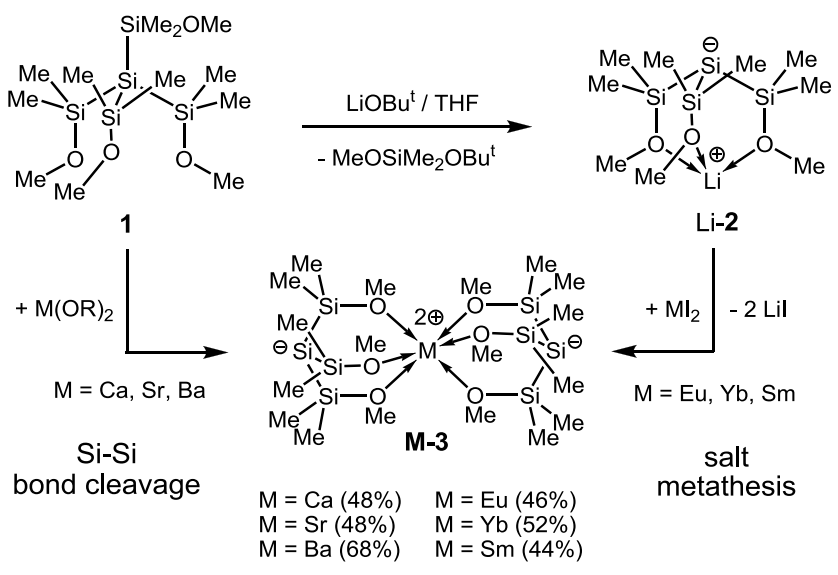

Scheme 2. Synthesis of M-3 (M = Ca, Sr, Ba, Eu, Yb, Sm).

In fact, combining THF solutions of the anhydrous salts $\mathrm{MI}_{2}(\mathrm{M}$ $=\mathrm{Eu}, \mathrm{Yb}, \mathrm{Sm})$, resp., with $\left[\mathrm{Si}\left(\mathrm{SiMe}_{2} \mathrm{OMe}\right)_{3} \mathrm{Li}\right]_{\infty}$, ( $\left.\mathrm{Li}-2\right)$, derived from the reaction of $\mathbf{1}$ with $\mathrm{LiOBu}^{\mathrm{t}}$ in $\mathrm{THF}^{2 \mathrm{f}}$, generated upon standing at room temperature for several hours crystalline precipitates of the europium, ytterbium and samarium silanides, M-3, in acceptable isolated yields (Scheme 2). The use of lithium silanide, $\mathrm{Li}-2$, as the nucleophile was crucial to the isolation of "salt-free" M-3 in high purity as the byproduct LiI formed during the course of the reaction is well soluble in THF at room temperature and did not co-precipitate with $\mathrm{M}-\mathbf{3}$. The isolated compounds $\mathrm{M}-\mathbf{3}$ ( $\mathrm{M}=$ $\mathrm{Eu}, \mathrm{Yb}, \mathrm{Sm}$ ) are extremely air-and moisture sensitive, but appear to be stable at room temperature for extensive periods of time upon storage in a glove box, while THF solutions of M-3 very slowly decompose over time at room temperature. 
Table 1. Average distances $[\AA]$ and angles $\left[{ }^{\circ}\right]$ of $\left[\mathrm{Si}\left(\mathrm{SiMe}_{2} \mathrm{OMe}\right)_{3}-\kappa^{3}\right]_{2} \mathrm{M},(\mathrm{M}-3),(\mathrm{M}=\mathrm{Mg}, \mathrm{Ca}, \mathrm{Sr}, \mathrm{Ba}, \mathrm{Eu}, \mathrm{Yb}, \mathrm{Sm})$.

\begin{tabular}{|c|c|c|c|c|c|c|c|}
\hline M-3 & $\mathrm{Mg}-3^{\mathrm{a}}$ & $\mathrm{Ca}-3^{\mathrm{a}}$ & $\mathrm{Yb}^{-3^{b}}$ & $\mathrm{Sr}-3^{\mathrm{a}}$ & $\mathrm{Eu}-3^{b}$ & $\mathrm{Sm}-3^{b}$ & $\mathrm{Ba}-3^{\mathrm{a}}$ \\
\hline $\mathrm{r}\left(\mathrm{M}^{2+}\right)^{\mathrm{c}}$ & 0.72 & 1.00 & 1.02 & 1.16 & 1.17 & 1.22 & 1.36 \\
\hline $\mathrm{Si}-\mathrm{Si}$ & 2.30 & 2.30 & 2.30 & 2.30 & 2.30 & 2.31 & 2.31 \\
\hline $\mathrm{Si}-\mathrm{O}$ & 1.72 & 1.70 & 1.70 & 1.69 & 1.70 & 1.70 & 1.70 \\
\hline $\mathrm{M}-\mathrm{O}$ & 2.15 & 2.38 & 2.43 & 2.51 & 2.52 & 2.54 & 2.66 \\
\hline $\mathrm{M}^{\cdots} \mathrm{Si}^{-}$ & 3.98 & 3.79 & 3.72 & 3.72 & 3.68 & 3.69 & 3.70 \\
\hline Si-O-M & 128 & 120 & 117 & 116 & 115 & 115 & 114 \\
\hline $\mathrm{Si}-\mathrm{Si}-\mathrm{Si}$ & 95 & 105 & 106 & 108 & 108 & 108 & 109 \\
\hline
\end{tabular}

Even though insoluble in hydrocarbons and poorly soluble in $\mathrm{THF}, \mathrm{Yb}-3$ was characterized in solution by ${ }^{1} \mathrm{H}-,{ }^{13} \mathrm{C}$ - and ${ }^{29} \mathrm{Si}-$ NMR spectroscopy using THF- $d_{8}$ as solvent. The paramagnetic species Eu-3 and Sm-3 were characterized by combustion analysis. In addition, the solid-state structures of $\mathrm{M}-3 \mathrm{M}=\mathrm{Eu}, \mathrm{Yb}$, $\mathrm{Sm}$ ) were determined by X-ray crystallography and the results for Yb-3 are exemplary shown in Figure 1 along with selected average bond lengths and angles of all structurally characterized metal silanides (Table 1) and the alkaline earth metals silanides $\mathbf{M g - 3}$, $\mathrm{Ca}-\mathbf{3}, \mathrm{Sr}-\mathbf{3}$ and Ba-3, previously reported. ${ }^{7}$ Compounds Eu-3, Yb$\mathbf{3}$ and $\mathrm{Sm}-\mathbf{3}$ are isostructural featuring spirocyclic bicyclooctane structures in which the central metal ions are octahedrally coordinated by six methoxy groups via dative bond interactions. To our knowledge, M-3 are the first examples of truly zwitterionic silanides that contain rare-earth metal cations regardless of their formal oxidation state.

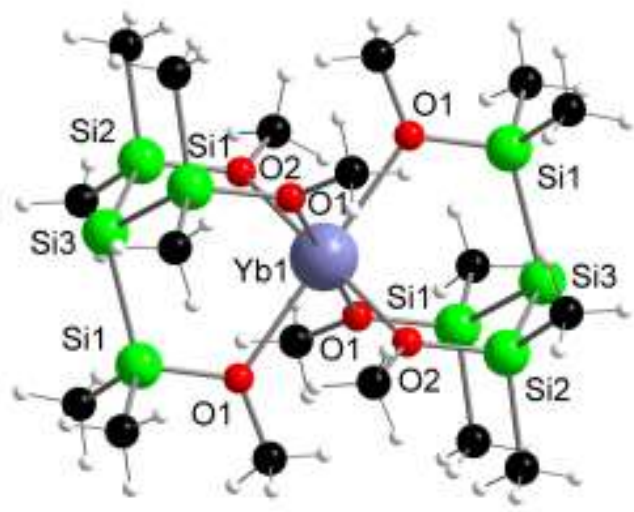

Figure 1. Solid-state structure of Yb-3 (disorder is not shown for clarity; black $=$ carbon, white $=$ hydrogen $)$.

The structural parameters of $\mathrm{M}-\mathbf{3}(\mathrm{M}=\mathrm{Eu}, \mathrm{Yb}, \mathrm{Sm})$ are fairly similar, except the $\mathrm{M}-\mathrm{O}$ distances, which increase as the size of the metal ion becomes larger. Note that the $\mathrm{M}^{\cdots} \mathrm{S}$ Si distances in $\mathrm{M}$ 3 (3.68-3.72 $\AA$ ) are longer than in the very few reported nonzwitterionic divalent rare-earth metals silanides; $\begin{array}{llll}\left(\mathrm{Me}_{3} \mathrm{Si}\right)_{3} \mathrm{SiYbCp} *(\mathrm{THF})_{2} & (3.03 & \AA & 12\end{array}$ $\left(\mathrm{Me}_{3} \mathrm{Si}\right)_{3} \mathrm{SiYb}\left[\mathrm{N}\left(\mathrm{SiMe}_{3}\right)_{2}\right]_{2} \mathrm{~K}(3.04 \AA)^{13},\left(\mathrm{Ph}_{3} \mathrm{Si}\right)_{2} \mathrm{Yb}(\mathrm{THF})_{4}(3.16$ $\AA)^{14},\left[\mathrm{Cp}{ }_{2} \mathrm{Eu}(\mathrm{THF}) \mathrm{SiH}_{3} \mathrm{~K}(\mathrm{THF})\right](3.24 \AA)^{15}$ and the silylene complex $\left[\mathrm{Cp}_{2}{ }_{2} \mathrm{SmSi}\left[\mathrm{N}\left(\mathrm{Bu}^{\mathrm{t}}\right) \mathrm{CH}\right]_{2}\right]_{3}(3.19 \AA){ }^{16}$ indicating only weak electrostatic interactions between the silyl anion and the metal cation in M-3. A structural comparison of the rare-earth with the alkaline earth derivatives M-3 reveals striking similarities (Table 1). For example, the Si-Si distances [ca. 2.30-2.31 $\AA$ ] and, except for Mg-3, the $\mathrm{Si}-\mathrm{O}$ [1.69-1.70 $\mathrm{A}]$ and $\mathrm{Si} \cdots \mathrm{M}$ [3.68-3.79 $\AA$ ] distances as well as the $\mathrm{Si}-\mathrm{Si}-\mathrm{Si}\left[105-109^{\circ}\right]$ and $\mathrm{Si}-\mathrm{O}-\mathrm{M}$ [114$120^{\circ}$ ] angles are very close to each other. The $\mathrm{M}-\mathrm{O}$ distances, on the other hand, appear to be a function of the metal cation radius; e. g., the larger the radius of $\mathrm{M}^{2+}$ the larger the $\mathrm{M}-\mathrm{O}$ distance.

To elucidate the donor ability of the "naked" silyl anions, $\mathrm{Yb}-3$ was reacted with $\mathrm{BPh}_{3}$, a medium Lewis acid ${ }^{17}$, and $\mathrm{W}(\mathrm{CO})_{6}$, known to undergo substitution reactions with loss of CO. ${ }^{18-20}$ In fact, the reaction with of two equivalents of $\mathrm{BPh}_{3}$ in THF resulted in the formation of a micro-crystalline precipitate identified by multi-nuclei NMR spectroscopy and elemental analysis as $\left[\mathrm{Ph}_{3} \mathrm{BSi}\left(\mathrm{SiMe}_{2} \mathrm{OMe}\right)_{3}-\kappa^{3}\right]_{2} \mathrm{Yb}(\mathrm{THF})(\mathrm{Yb}-4)$. The ${ }^{29} \mathrm{Si}-\mathrm{NMR}$ data are most instructive because the signal of the central silicon anion drastically shifted to higher field, from -202.9 in zwitterion $\mathrm{Yb}-3$ to $-132.0 \mathrm{ppm}$ upon addition of $\mathrm{BPh}_{3}$. The ${ }^{11} \mathrm{~B}$ NMR displays a broad signal at ca. $-8.0 \mathrm{ppm}$ indicative of a boron atom in a tetrahedral coordination environment. The reaction of $\mathrm{Yb}-3$ with $\mathrm{W}(\mathrm{CO})_{6}$ proceeded similarly giving rise to the formation of a trimetallic zwitterion of formula $\left[(\mathrm{CO})_{5} \mathrm{WSi}\left(\mathrm{SiMe}_{2} \mathrm{OMe}\right)_{3}-\kappa^{3}\right]_{2} \mathrm{Yb}$ $(\mathrm{Yb}-5)$ as confirmed by NMR spectroscopy and the results of elemental analysis (Scheme 3). Again, in the ${ }^{29} \mathrm{Si}-\mathrm{NMR}$ spectrum the signal of the central anionic silicon shifted to higher field, from -202.9 in zwitterion $\mathrm{Yb}-\mathbf{3}$ to $-152.0 \mathrm{ppm}$ upon addition of $\mathrm{W}(\mathrm{CO})_{6}$. The IR spectrum (THF) of the carbonyl region of $\mathrm{Yb}-5$ displays four bands at $2042 \mathrm{~cm}^{-1}(\mathrm{~m}), 1957 \mathrm{~cm}^{-1}(\mathrm{~m}), 1907 \mathrm{~cm}^{-1}$ (vs) and $1878 \mathrm{~cm}^{-1}$ (s). These values are characteristic of $\mathrm{M}\left[\mathrm{W}(\mathrm{CO})_{5} \mathrm{X}\right]$ species, that do not have rigorous $C_{4 \mathrm{v}}$ geometry, ${ }^{21}$ and are similar to the values of the tungsten silyl complexes reported previously. ${ }^{2 \mathrm{i}, 18-20}$

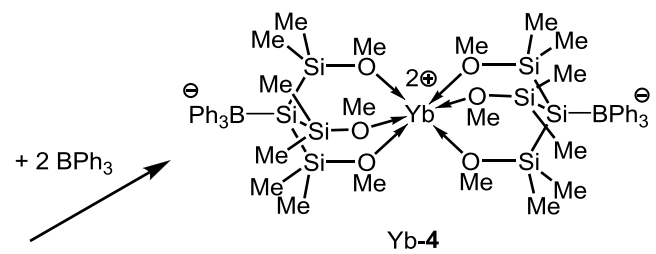

$\mathrm{Yb}-3$

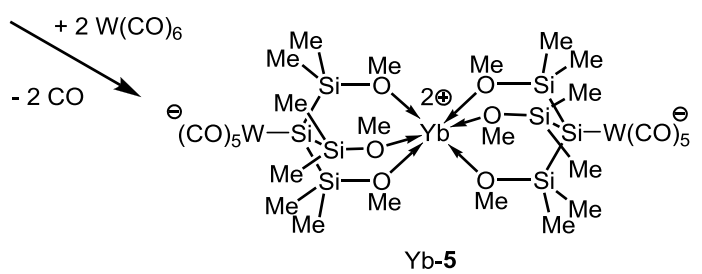

Scheme 3. Synthesis of Yb-4 and Yb-5.

The solid-state structure of $\mathrm{Yb}-\mathbf{4}$ was confirmed by singlecrystal X-ray crystallography; suitable crystals were grown from THF at room temperature (Figure 2). Yb-4 contains two molecules of non-coordinating THF; crystalline samples which had been exposed to vacuum for ca. 2 hours lost approximately one molecule of THF. Similar to Yb-3, silyl borate Yb-4 features a 
central spirocyclic bicyclooctane structure with the central ytterbium ion being octahedrally coordinated by six methoxy groups. The triphenylborane units are bound to the central silicon atoms, generating two tetra-coordinated silyl borate units. The $\mathrm{Si}-\mathrm{B}$ distances $[2.17 \AA]$ are in agreement with those of the structurally related silyl borate complexes $\left[\left(\mathrm{C}_{6} \mathrm{~F}_{5}\right)_{3} \mathrm{BSi}\left(\mathrm{SiMe}_{2} \mathrm{OCH}_{2} \mathrm{CH}_{2} \mathrm{OMe}\right)_{3}-\kappa^{6}-\mathrm{K}\right] \quad[2.17 \AA$ $\left[\left(\mathrm{C}_{6} \mathrm{~F}_{5}\right)_{3} \mathrm{BSi}\left(\mathrm{SiMe}_{2} \mathrm{OCH}_{2} \mathrm{CH}_{2} \mathrm{OMe}\right)_{3}-\kappa^{6}-\mathrm{Zn}\right]\left[\mathrm{MeB}\left(\mathrm{C}_{6} \mathrm{~F}_{5}\right)_{3}\right] \quad[2.14$ $\AA]{ }^{8}$ Notably, upon coordination with $\mathrm{BPh}_{3}$ the average $\mathrm{Si}-\mathrm{Si}$ distance significantly increase from $2.30 \AA$ in $\mathrm{Yb}-3$ to $2.34 \AA$ in $\mathrm{Yb}-4$. Also the $\mathrm{Si}-\mathrm{O}$ distances slightly increase [from 1.70 to 1.72 $\AA$ ], while the $\mathrm{M}-\mathrm{O}$ distances remain unchanged [both $2.43 \AA$ ].

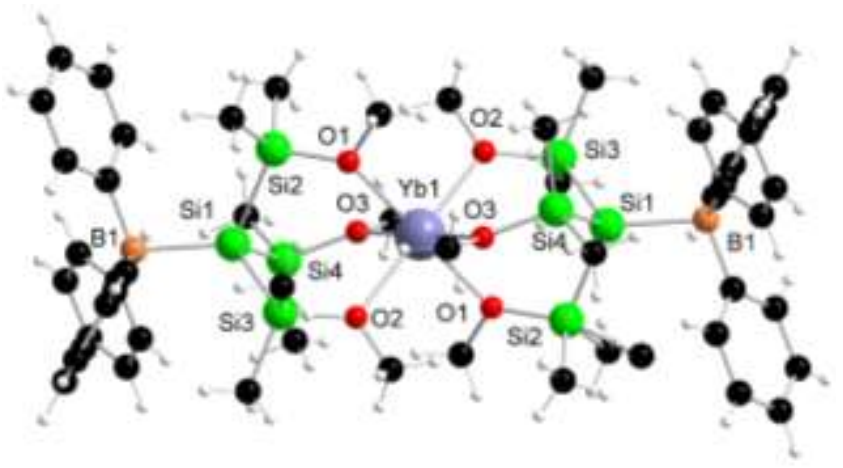

Figure 2. Structure of Yb-4 (THF molecules are omitted for clarity; black $=$ carbon, white $=$ hydrogen $)$. Average distances $[\AA]$ and angles [ $\left.{ }^{\circ}\right]$ : $\mathrm{Yb}-\mathrm{O} 2.43, \mathrm{Si1}-\mathrm{B} 12.17, \mathrm{Si}-\mathrm{Si} 2.34, \mathrm{Si}-\mathrm{O}$ 1.72, C-B 1.63, Si-Si-Si 102.6, Si-O-Yb 127.2.

In conclusion, the synthesis and structures of the first zwitterionic divalent rare-earth metal silanides of formula $\left[\mathrm{Si}\left(\mathrm{SiMe}_{2} \mathrm{OMe}\right)_{3}-\kappa^{3}\right]_{2} \mathrm{M}(\mathrm{M}-3)$, where $\mathrm{M}=\mathrm{Eu}, \mathrm{Yb}, \mathrm{Sm}$, is reported. M-3 compounds feature spirocyclic bicyclooctane structures in which the central rare earth metal ions are being octahedrally coordinated by six methoxy groups similar to that seen in the alkaline earth zwitterions $\mathrm{M}-3$ ( $\mathrm{M}=\mathrm{Ca}, \mathrm{Sr}, \mathrm{Ba})$. $\mathrm{Yb}-3$ reacts with $\mathrm{BPh}_{3}$ and $\mathrm{W}(\mathrm{CO})_{6}$, resp., to produce the zwitterions $\mathrm{Yb}-4$ and $\mathrm{Yb}$ 5 in good yields.

\section{ASSOCIATED CONTENT}

\section{Supporting Information}

Experimental procedures and characterization data for all compounds and CIF file for Yb-3 (CCDC 1050382), Eu-3 (CCDC 1050383), Sm-3 (CCDC 1050381) and Yb-4 (CCDC 1050384). This material is available free of charge via the Internet at http://pubs.acs.org.

\section{AUTHOR INFORMATION}

\section{Corresponding Author}

* Department of Chemistry and Biochemistry, Texas Tech University, Box 1061, Lubbock, Texas, USA, 79409-1061, clemens.krempner@ttu.edu.

\section{Notes}

The authors declare no competing financial interests.

\section{ACKNOWLEDGMENT}

The support of our work by Texas Tech University is greatly acknowledged. David Purkiss is thanked for carrying out the
NMR experiments and the NSF for purchase of a JEOL ECS-400 Spectrometer (CRIF-MU CHE-1048553).

\section{REFERENCES}

1 For reviews on silyl anions see: a) Lickiss, P. D.; Smith, C. Coord. Chem. Rev. 1995, 145, 75; b) Tamao, K.; Kawachi, A. Adv. Organomet. Chem. 1995, 38, 1; c) Wiberg, N. Coord. Chem. Rev. 1997, 163, 217; d) Belzner, J.; Dehnert, U. In The Chemistry of Organic Silicon Compounds, Vol. 2; Rappoport, Z.; Apeloig, Y., Ed.; Wiley: Chichester, 1998; p 779; e) Sekiguchi, A.; Lee, V.; Nanjo, M. Coord. Chem. Rev. 2002, 210, 11; f) Lerner, H.-W. Coord. Chem. Rev. 2005, 249, 781; g) Marschner, C. Organometallics 2006, 25, 2110.

2 For donor substituted silyl anions see: a) Belzner, J.; Dehnert U.; Stalke, D., Angew. Chem., Int. Ed. Engl. 1994, 33, 2450-2; b) Belzner, J.; Detomi, N.; Ihmels, H.; Noltemeyer, M., Angew. Chem. 1994, 106, 1949-50; c) Fischer, R.; Baumgartner, J.; Kickelbick, G.; Marschner, C., J. Am. Chem. Soc. 2003, 125, 34143415; d) Guliashvili, T.; El-Sayed, I.; Fischer, A.; Ottosson, H., Angew. Chem., Int. Ed. Engl. 2003, 42, 1640-1642; e) Likhar, P. R.; Zirngast, M.; Baumgartner, J.; Marschner, C., Chem. Comm. 2004, 1764-1765; f) Krempner, C.; Chisholm, M. H.; Gallucci, J., Angew. Chem., Int. Ed. 2008, 47, 410-413; g) Zirngast, M.; Baumgartner, J.; Marschner, C., Eur. J. Inorg. Chem. 2008, 10781087; h) Zirngast, M.; Flock, M.; Baumgartner, J.; Marschner, C., J. Am. Chem. Soc. 2008, 130, 17460-17470; i) McNerney, B.; Whittlesey, B.; Krempner, C., Eur. J. Inorg. Chem. 2011, 11, 16991702; j) Armbruster, F.; Meyer, J.; Baldes, A.; Burgos, P. O.; Fernandez, L.; Breher, F., Chem. Comm. 2011, 47, 221-223.

3 Hitchcock, P. B.; Lappert, M. F.; Layh, M., Chem. Comm. 1998, 2179-2180.

4 Farwell, J. D.; Hitchcock, P. B.; Lappert, M. F.; Protchenko, A. V., Chem. Commun. 2005, 2271-2273.

5 Armbruster, F.; Fernandez, I.; Breher, F., Dalton Trans. 2009, 56125626.

6 Li, H.; Hope-Weeks, L. J.; Krempner, C., Chem. Comm. 2011, 47, 4117-4119.

7 Carlson, B.; Aquino, A. J. A.; Hope-Weeks, L. J.; Whittlesey, B.; McNerney, B.; Hase, W. L.; Krempner, C., Chem. Comm. 2011, 47, 11089-11091.

8 Li, H.; Hung-Low, F.; Krempner, C., Organometallics, 2012, 31, 7117-7124.

9 Armbruster, F.; Augenstein, T.; Oña-Burgos, P.; Breher, F., Chem. Eur. J. 2013, 19, 17899-17906.

10 Styra, S.; González-Gallardo, S.; Armbruster, F.; Oña-Burgos, P.; Moos, E.; Vonderach, M.; Weis, P.; Hampe, O.; Grün, A.; Schmitt, Y.; Gerhards, M.; Menges, F.; Gaffga, M.; Niedner-Schatteburg, G.; Breher, F. Chem. Eur. J. 2013, 19, 8436-8446.

11 For tridentate tris(phosphinomethyl)borate-based zwitterions see: a) Lu, C. C.; Peters, J. C. J. Am. Chem. Soc. 2004, 126, 15818; b) Betley, T. A.; Peters, J. C. Angew. Chem., Int. Ed. 2003, 42, 2385; c) Thomas, J. C.; Peters, J. C. J. Am. Chem. Soc. 2003, 125, 8870; d) Lu, C. C.; Saouma, C. T.; Day, M. W.; Peters, J. C. J. Am. Chem. Soc. 2007, 129, 4; e) Hendrich, M. P.; Gunderson, W.; Behan, R. K.; Green, M. T.; Mehn, M. P.; Betley, T. A.; Lu, C. C.; Peters, J. C. Proc. Natl. Acad. Sci. U. S. A. 2006, 103, 17107; f) Jenkins, D. M.; Peters, J. C. J. Am. Chem. Soc. 2005, 127, 7148, and references therein

12 Corradi, M. M.; Frankland, A. D.; Hitchcock, P. B.; Lappert, M. F.; Lawless, G. A., Chem. Comm. 1996, 2323.

13 Niemeyer, M., Inorg. Chem. 2006, 46, 9085.

14 Bochkarev, L. N.; Makarov, V. M.; Hrzhanovskaya, Y. N.; Zakharov, L. N.; Fukin, G. K.; Yanovsky, A. I.; Struchkov, Y. T., J. Organomet. Chem. 1994, 467, C3.

15 Hou, Z.; Zhang, Y.; Nishiura, M.; Wakatsuki, Y. Organometallics, 2003, 22, 129.

16 Evans, W. J.; Perotti, J. M.; Ziller, J. W.; Moser, D. F.; West, R., Organometallics 2003, 22, 1160.

$17 \mathrm{Li}, \mathrm{H}$. ; Aquino, A. J.; Cordes, D. B.; Hung-Low, F; Hase, W. L.; Krempner, C., J. Am. Chem. Soc. 2013, 135, 16066-16069.

18 Palitzsch, W.; Beyer, C.; Boehme, U.; Rittmeister, B.; Roewer, G., Eur. J. Inorg. Chem. 1999, 1813-1820.

19 Heyn, R. H.; Tilley, T. D., Inorg. Chem. 1990, 29, 4051-4055. 


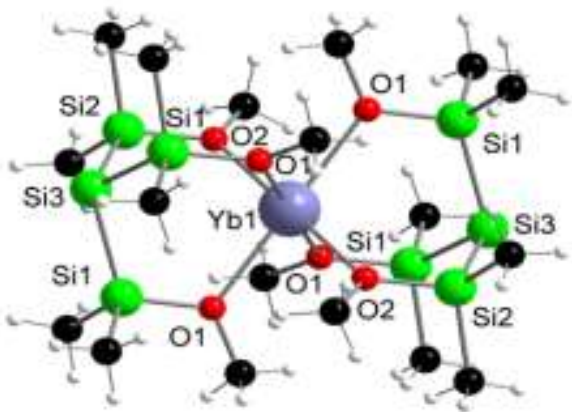

Zwitterionic Ytterbium Silanide
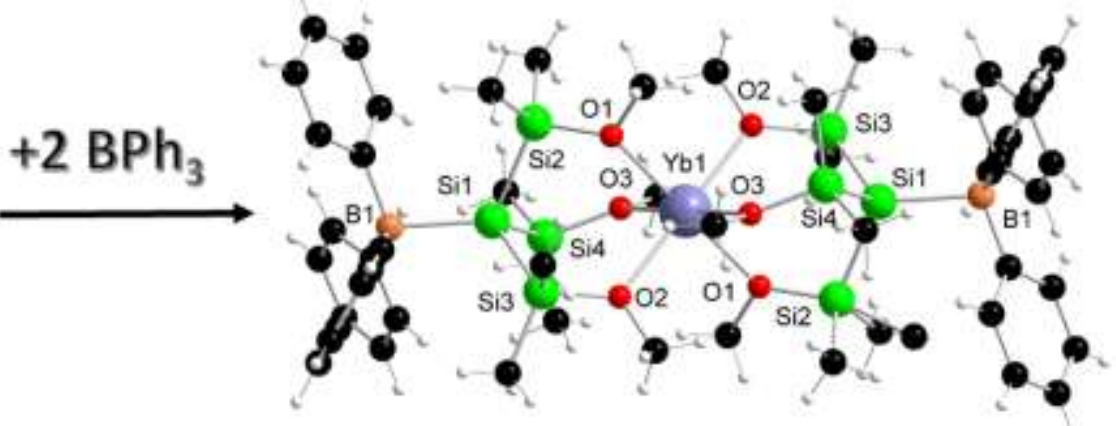

Zwitterionic Ytterbium Silyl Borate

The synthesis and structures of the first zwitterionic divalent rare-earth metal silanides of the formula $\left[\mathrm{Si}\left(\mathrm{SiMe}_{2} \mathrm{OMe}\right)_{3}-\kappa^{3}\right]_{2} \mathrm{M},(\mathrm{M}-3)$, where $\mathrm{M}=\mathrm{Eu}, \mathrm{Yb}, \mathrm{Sm}$, is reported. $\mathrm{M}-3$ compounds feature spirocyclic bicyclooctane structures in which the central rare-earth metal ions are being octahedrally coordinated by six methoxy groups. The reaction of $\mathrm{Yb}-3$ with $\mathrm{BPh}_{3}$ and $\mathrm{W}(\mathrm{CO})_{6}$, resp., generated the trinuclear zwitterions $\left[\mathrm{Ph}_{3} \mathrm{BSi}\left(\mathrm{SiMe}_{2} \mathrm{OMe}\right)_{3}-\kappa^{3}\right]_{2} \mathrm{Yb},(\mathrm{Yb}-\mathbf{4})$, and $\left[(\mathrm{CO})_{5} \mathrm{WSi}\left(\mathrm{SiMe}_{2} \mathrm{OMe}\right)_{3}-\kappa^{3}\right]_{2} \mathrm{Yb},(\mathrm{Yb}-5)$, in good yields. 